\title{
The Use and Interpretation of the Psalms in early Pentecostalism as Reflected in The Apostolic Faith from 1906 through 1915
}

\author{
LEE ROY MARTIN (UNISA)
}

\begin{abstract}
This article examines the twenty-five references to the book of Psalms in the first ten years of The Apostolic Faith, the periodical that was published by William J. Seymour at the Azusa St. Revival. The article demonstrates that the early Pentecostal interpretation of the psalms was neither monolithic nor simple. The early writers utilized a variety of methods and approaches, depending upon their purpose for writing. Seymour and the other contributors to his periodical used the psalms in at least five different ways: 1. as affirmations of doctrine, 2. as allegories, 3. as analogous to Pentecostal experience, 4. as affective argument, and 5. as assurance and encouragement.
\end{abstract}

KEYWORDS: Wirkungsgeschichte; hermeneutics; experience; allegory; William J. Seymour; Azusa St.

\section{A INTRODUCTION}

This article presents an examination of the function and interpretation of the psalms in early Pentecostalism. Following the lead of recent works in constructive Pentecostal theology, this article examines the early Pentecostal periodical literature from the beginning of 1906 (when the Azusa St. revival began) to the end of $1915 .{ }^{1}$ According to Steven J. Land, who takes his cue from

* Article submitted: 24/02/2017; peer-reviewed: 22/03/2017; accepted: 17/08/2017. Lee Roy Martin, “The Use and Interpretation of the Psalms in Early Pentecostalism as Reflected in The Apostolic Faith from 1906 through 1915,” OTE 30/3 (2017): 725748. DOI: https://doi.org/10.17159/2312-3621/2017/v30n3a11

1 This method was pioneered by Kimberly E. Alexander, Pentecostal Healing: Models in Theology and Practice, JPTSup 29 (Blandford Forum, UK: Deo Publishing, 2006); and was followed by Larry R. McQueen, Toward a Pentecostal Eschatology: Discerning the Way Forward, JPTSup 39 (Blandford Forum, UK: Deo Publishing, 2012); Chris E.W. Green, Toward a Pentecostal Theology of the Lord's Supper (Cleveland, TN: CPT Press, 2012); and Melissa L. Archer, "I was in the Spirit on the Lord's day": A Pentecostal Engagement with Worship in the Apocalypse (Cleveland, TN: CPT Press, 2014). 
Walter J. Hollenweger, the first decade of the movement is crucial for establishing the "heart" of the Pentecostal tradition. ${ }^{2}$

This examination of Pentecostal testimonies, sermons, and essays aims to make the following contributions. Firstly, this Wirkungsgeschichtliche study of the early Pentecostal literature should correct any previously held misconceptions about the Pentecostal interpretation of the psalms. Secondly, the act of engaging with the early literature furthers the researcher's formation as a Pentecostal interpreter as it instils the Pentecostal affections. ${ }^{3}$ Thirdly, early Pentecostal approaches to the psalms can contribute towards the ongoing construction of contemporary Pentecostal hermeneutics. As with any renewal movement, Pentecostalism's core values and beliefs were generated in the heart and minds of its founders. That is not to say that contemporary constructive theology must follow the exact lines of the early tradition. However, if Pentecostal theology is to remain genuinely Pentecostal (rather than Evangelical plus glossolalia), any new paths that are constructed must remain faithful to the heart of the Pentecostal tradition. ${ }^{4}$ Church traditions are ever-changing and developing; therefore, continuous critical reflection is necessary.

Periodical literature is the focus of my investigation for two reasons. Firstly, the early Pentecostals produced few book-length works on theology. Most of the early theological discussions were carried on within the pages of numerous periodicals. Secondly, the Pentecostal movement had no central authority that was tasked with formulating guidelines for Pentecostal theology and practice. The periodicals, published by Pentecostal leaders and often

2 Steven J. Land, Pentecostal Spirituality (Cleveland, TN: CPT Press, 2010): 1; Walter J. Hollenweger, The Pentecostals (Peabody, MA: Hendrickson, 1988), 551.

3 See Land, Pentecostal, 47, 50, 52, 63, who argues that Pentecostal spirituality consists of orthodoxy (right belief/worship) and orthopraxy (right actions) integrated in the affections (orthopathy). The key Pentecostal affections, according to Land, are gratitude (thanks/praise), compassion (love/longing), and courage (confidence/hope). John C. Thomas, “'What the Spirit Is Saying to the Church': The Testimony of a Pentecostal in New Testament Studies,” in Spirit and Scripture: Exploring a Pneumatic Hermeneutic, ed. Kevin L. Spawn and Archie T. Wright (New York: T\&T Clark, 2012), 117, names five affections that correspond broadly to the elements of the Fivefold Gospel: Salvation/Gratitude, Sanctification/Compassion, Spirit Baptism/Courage, Healing/Joy, Return of Jesus/Hope. For more on a theological approach to the affections, see Gregory S. Clapper, John Wesley on Religious Affections: His Views on Experience and Emotion and Their Role in the Christian Life and Theology (Metuchen, NJ: Scarecrow Press, 1989), and Daniel Castelo, "Tarrying on the Lord: Affections, Virtues and Theological Ethics in Pentecostal Perspective," JPT 13/1 (2004): 31-56.

4 See Green, Toward a Pentecostal, 74-76. 
representing the various newly formed denominations, were the nearest things to authoritative theological voices.

In the ten-year period 1906-1915, I was able to locate 576 references to the psalms in the following Pentecostal periodicals: The Apostolic Faith (AFLA and the Portland, OR edition AFO), The Bridegroom's Messenger (BM), The Church of God Evangel (CGE), The Whole Truth (WT), The Latter Rain Evangel (LRE), The Pentecost (Pent), The Pentecostal Testimony (PT), Word and Witness (WWit), and The Christian Evangel/Pentecostal Evangel (CE/PE). ${ }^{5}$ The most popular psalms were as follows (with number of occurrences in parentheses): 103 (30), 119 (24), 91 (23), 51(20), 34 (18), 45 (16), 9 (14), 23 (14), 37 (14), and 107 (12). The most commonly cited verses were Ps 103:3 (20) "he healeth all thy diseases";6 9:17 (9) "the wicked shall be turned into hell”; 45:14-15 (5) "she shall be brought unto the king ...”; 46:10 (5) "Be still, and know that I am God: I will be exalted ..."; 107:20 (5) "He sent his word, and healed them"; 2:8 (4) "I will give thee the heathen for thine inheritance"; 8:4 (4) "What is man ... and the son of man ...?”; 42:11 (4) “Why art thou cast down ...?”; 51:17 (4) “The sacrifices of God are a broken spirit ...”; 91:10 (4) "He shall cover thee with his feathers, and under his wings thou shalt trust ...”; 110:3 (4) “... in the day of thy power, in the beauties of holiness ..."; and 119:105 (4) "Thy word is a lamp unto my feet ...."7

Time and space do not allow for an examination of all 576 references to the psalms. Therefore, I limit my detailed study to The Apostolic Faith, the

5 My research was conducted online through the Flower Pentecostal Heritage Center (https://ifphc.org/) and through the Consortium of Pentecostal Archives (https://pentecostalarchives.org/). From these sites, I searched the early periodicals for the words "Psalms," "Psa," and "Ps." The two sites produced different search results; therefore, I would encourage researchers to utilize both sites when searching for specific words. Full-text searches are incomplete, however, because some of the original texts were in poor condition when scanned and because writers sometimes omitted the Scriptural reference. Therefore, a close reading of the entire corpus would reveal a number of quotations that were not discovered through text searches.

6 Quotations of Scripture are from the KJV, the version that was almost always used in the early Pentecostal Literature.

7 Extending the search to 1940 reveals these Psalms as the most frequently cited: 119 (235); 103 (224); 37 (149); 91 (140); 34 (134); 2 (133); 23 (127); 107 (124); 51 (120); 1 (110); 46 (107); 27 (104); 100 (69); 22 (85); and 150 (29). Psalms 103, 119, 91, and 34 remain in the top five, but Ps 51 drops out, and Ps 2 moves up to number 6. Psalms 23, 34, 37, and 91 can be called psalms of trust/confidence. Psalm 119 is a Torah hymn that invites faithfulness to the "law of the Lord." Psalm 2 is highly Christological, and Pss 103 and 107 are songs of thanksgiving/testimony that contain references to healing. While every Psalm is cited at least once, the following psalms are cited the fewest number of times: 54 (1); 140 (3); 59 (4); 114 (4); 123 (4); 135 (4). 
periodical edited and published by William J. Seymour at the Azusa St. Mission in Los Angeles, California. The Apostolic Faith is chosen because of its widespread influence and because it represents the beginnings of the Pentecostal movement in the USA. By examining every reference in one periodical, I hope to be exempt from the accusation of choosing only those texts that fit my presuppositions.

The Apostolic Faith was published from 1906 to 1908 by William J. Seymour at The Apostolic Faith Mission. The four-page newspaper reported on the Azusa Street revival in Los Angeles and included other news, testimonies, articles, and letters from the Pentecostal movement worldwide. The articles focused on distinctive Pentecostal doctrines, and the testimonies recounted dramatic Pentecostal experiences such as healings, miracles, sanctifications, and Spirit Baptisms. Florence Crawford, who spent time at the Azusa St. Revival, began a version of The Apostolic Faith in Portland, OR in 1908 that continued until 1929. I discovered eighteen references to the psalms in The Apostolic Faith (1906 to 1908) and seven more in the Portland, OR edition between 1909 and 1915. I have classified these 25 references into five categories based upon the hermeneutical function of the biblical citation. ${ }^{8}$

\section{B THE PSALMS AS AFFIRMATIONS OF DOCTRINE}

The first category consists of biblical citations that are used to support the beliefs of the early Pentecostals. In the Apostolic Faith, we find the psalms undergirding four doctrines: divine healing, hell, creation, and sanctification.

\section{$1 \quad$ Divine Healing}

$8 \quad$ I am addressing all 25 references except for the two cases in which the biblical text itself is not discussed or interpreted at all. First, in an example of glossographia, a man who calls himself "Bro. Junk" testifies that he wrote Ps 46:3 in Hebrew while "under the power of God." See AFLA 1/4 (Dec 1906): 1. Second, it is stated only that a woman preached on Ps 103. See AFLA 1/6 (Feb-Mar 1907): 8. Although not found in the first ten years of $A F L A$, a sixth prominent use of the Psalms in the early literature is as an expression of the writer's praise. See, for example, the use of Ps 105:1-2 in $B M$ 6/140 (Sept 15, 1913): 3; Ps 79:13 in BM 7/141 (Oct 1, 1913): 1; Ps 107:22 in BM 7/145 (Dec 1, 1913): 2; Ps 34:2 in CGE 6/31 (July 31, 1915): 3; Ps 117 in $B M$ 2/44 (Aug 15, 1909): 3; Ps 31:19 in BM 3/63 (June 1, 1910): 3; and Pss 9:1 and 104:24 in $B M 4 / 72$ (Oct 15, 1910): 2. A seventh category might be added in which the citations from the Psalms are used as exhortations to belief, action, or behavior. See Pss 110:3, 62:1, and 50:17 in $B M$ 1/7 (Feb 1, 1908): 2; Ps 141:5 in $B M$ 2/29 (Jan 1, 1909): 4; Pss 37:7 and 143:8, 10 in BM 2/36 (Apr 15, 1909): 4; Ps 92:12 in BM 2/43 (Aug 1, 1909): 1; Ps 66:18 in BM 3/57 (Mar 1, 1910): 4; and Ps 119:66 in BM 3/60 (Apr 15, 1910): 4. 
Divine healing was a key element of the early Pentecostal movement, and Jesus as healer was one of the five points of what was called the "full gospel" or the "fivefold gospel." 9 The Pentecostal belief in divine healing is based upon many biblical texts, and among them is Ps 103:3: "He healeth all thy diseases." 10 Ps 103 is The Apostolic Faith's most commonly referenced psalm by far (nine references), and it occurs in the Apostolic Faith Movement's statement of faith that is printed in the first issue of The Apostolic Faith:

Seeking healing. - He must believe that God is able to heal. - Ex.

15:26: "I am the Lord that healeth thee." James 5:14; Psa. 103:3; 2

Kings 20:5; Matt. 8:16, 17; Mark 16:16, 17, $18 .{ }^{11}$

This statement is repeated in The Apostolic Faith 1:2, 1:3, 1:10, 1:12, and 2:13. It is also published in the first issue of The Apostolic Faith (Oregon) ${ }^{12}$ and in issues 16 and 18; but the statement was rewritten and expanded without explanation in 1909, omitting both Exod 15:26 and Ps 103:3 (but adding Isa 53:4, 5).

Psalm 107:20 is also used to support the teaching on healing. It appears along with Jas 5:13; Prov 4:20; Exod 15:26; and John 3:14 under the heading "Healing." The writer states, "We read in Ps 107:20, 'He sent his Word and healed them, and delivered them from their distresses.'”13

\section{$2 \quad$ Hell}

Psalm 9:17 is cited three times as support for the doctrine of hell. Under the title "Awful Realities of Hell,” the author asks rhetorically, "Do you believe in hell?” The writer continues, noting Ps 9:17,

Brother, it makes no difference what you or I believe, that does not do away with God's word. Hell exists in its awful reality, whether you

9 The fivefold gospel holds that Jesus is savior, sanctifier, baptizer in the Holy Spirit, healer, and soon-coming king. See Donald W. Dayton, Theological Roots of Pentecostalism (Peabody, MA: Hendrickson Publishers, 1987), 20; Land, Pentecostal, 38, 57, 89-90; and Thomas, “Testimony of a Pentecostal," 117.

10 Pentecostals inherited the use of Ps 103:3 as support for the doctrine of divine healing from the nineteenth-century healing movement. See, for example, Albert B. Simpson, The Fourfold Gospel, 4th ed. (New York: Christian Alliance Publishing Co., 1890), 14.

11 AFLA 1/1 (Sept 1906): 2.

12 AFO 19 (Feb-Mar 1909): 2.

13 AFLA 1/6 (Feb-Mar 1907): 6. Other psalms cited in support of divine healing include Ps 30:2 in BM 2/35 (Apr 1, 1909): 1 and Ps 105:37 in BM 3/60 (Apr 15, 1910): 4. 
believe it or not, and multitudes are plunging headlong into it. "The wicked shall be turned into hell, and all the nations that forget God.”

Further support for the doctrine of hell is then given by Scriptural quotations from the gospels and the book of Revelation. ${ }^{14}$

A few months later, William Seymour addressed the question as to whether hell is a place of annihilation or a place of eternal punishment. He begins by stating, "Many people today do not believe in an everlasting hell."15 Seymour's article is a direct refutation of Charles Parham's belief in the annihilation of the wicked, a doctrine that Parham had promoted as early as March 1899 in the first issue of his periodical. ${ }^{16}$ Apparently, Parham had been convinced by his wife's grandfather that the wicked do not suffer eternally. ${ }^{17}$ After citing Luke 16:19, Rev 20:10, and Matt 18:8, Seymour turns to the Psalter:

Dear loved ones, there is an awful hell. God teaches us in Ps 9, 17, "The wicked shall be turned into hell, and all the nations that forget God." We find the punishment of the wicked taught us from the closed gates of Eden all the way down ... May God help men everywhere to repent of their sins and accept the precious blood of Jesus Christ that cleanses from all sin.

Seymour apparently interprets Ps 9:17 in the light of the NT teaching on hell. While it is true that Ps 9:17 asserts "the punishment of the wicked," the punishment described in Ps 9 comes in the form of defeat and death. When the enemy "turns" to attack (v. 3) they will be "turned" (v. 17) to Sheol, meaning that they will be killed (cf. Pss 31:17; 55:15; 63:9). Moreover, their "name" will be "blotted out" (v. 5), but the poor will not "be forgotten" (v. 18). It should be pointed out, however, that although Ps 9:17 does not directly engage the question of eternal punishment, it may be taken as legitimate support for Seymour's position, given the fact that Sheol is represented in some OT texts as an ongoing state of existence.

14 AFLA 1/2 (Oct 1906): 2.

15 AFLA 1/5 (Jan 1907): 2.

16 Seymour was Parham's student at his Topeka Bible School where in 1901 Agnes Ozman spoke in tongues, an event that launched Parham as a teacher of the doctrine of tongues as initial evidence of Spirit baptism.

17 See Iain MacRobert, The Black Roots and White Racism of Early Pentecostalism in the USA (New York: St. Martin’s Press, 1988), 43. Annihilationism was growing in popularity partly because of the Seventh-Day Adventist Church. Ellen G. White had affirmed the doctrine of total annihilation, one aspect of the teaching that the Adventists call “conditional immortality,” as early as 1843. See Gary Land, Historical Dictionary of the Seventh-day Adventists, $2^{\text {nd }}$ ed. (New York: Rowman \& Littlefield, 2015), 77-78. 
In addition to his use of Ps 9:17 as doctrinal support, Seymour employs the text as an emotional appeal: "Dear loved ones, there is an awful hell. God teaches us in Ps 9:17 ....” What begins as doctrinal affirmation concludes with a plea for unbelievers to repent and turn to Jesus Christ. He urges, "May God help men everywhere to repent ...” Seymour's hermeneutic is always missional - his theology and his ministry are integrated.

The third reference to Ps 9:17 appears in an article that is partly personal testimony and partly an evangelistic appeal to unbelievers. ${ }^{18}$ After beginning with Luke 19:10 "The Son of Man is come to seek and to save that which was lost," the writer testifies to having been a sinner who went to church but "did not know Jesus” and who did not want to end up in hell. The writer goes on,

Then we read in Psalms 9:17, "the wicked shall be turned into hell and all the nations that forget God.” O sinner, where will you spend eternity? Will you spend it with the devil and his angels, or will you spend it with God and his angels?

The emotional appeal continues to the end of the article with support from other biblical texts and affirmations of Jesus's ability to satisfy the hunger and thirst of those who will call upon him. Even in this doctrinal essay, the writer takes advantage of the affective dimension of the text.

\section{Creation of Adam in the Image of God}

In December of 1906, after "seven Months of Pentecostal Showers," an article appeared in The Apostolic Faith that functioned as a testimony, apology, and doctrinal explanation of the new revival movement on Azusa Street. After sharing the origins of the revival and a defense of William Seymour as "simply a humble pastor of the flock," the writer states the theological position of the movement:

We believe in old time repentance, old time conversion, old time sanctification, healing of our bodies and the baptism with the Holy Ghost. We believe that God made Adam in His own image, according to Gen 5:1; Ps. 8:4; and Matt. 19:4. We do not believe in any eighth day creation, as some have taught, and we do not believe in the annihilation of the wicked. We stand on Bible truth without compromise. We recognise every man that honors the blood of Jesus Christ to be our brother, regardless of denomination, creed, or doctrine. But we are not willing to accept any errors, it matters not how charming or sweet they may seem to be. ${ }^{19}$

18 AFLA 1/12 (Jan 1908): 4.

19 AFLA 1/4 (Dec 1906): 1. 
732 Martin, "Psalms in Early Pentacostalism,” OTE 30/3 (2017): 725-748

The citations of Gen 5:1, Ps 8:4, and Matt 19:4 are apparently intended to counter the divisive "eighth day creation" theory that was taught by Charles Parham (among others). ${ }^{20}$ Although there are variations on the teaching, the eighth-day creation theory proposes that there were two separate human creations, one on the sixth day (Gen 1:27) and another on the eighth day (Gen 2:7), resulting in two different species of humans. On the one hand, the sixth-day humans were a race created in the image of God; but, unlike Adam, they were not infused with the breath of God (Gen 2:7). On the other hand, the eighth-day Adamic race was not "created" (Gen 1:27) but was "formed from the ground" (Gen 2:7); therefore, Adam was not made in the image of God. Moreover, the sixth-day race had no promise of a redeemer because the redeemer would be from the seed of Eve (Gen 3:15) who was made on the eighth day. When Cain went to the land of Nod, he married a sixth-day woman and thus defiled the Adamic race with the first interracial marriage. ${ }^{21}$ The illicit practice of interracial marriage was made widespread in Gen 6:1-4 when the "sons of God" (eighthday Adamic race) intermarried with the "daughters of men" (sixth-day race). The statement from The Apostolic Faith counters the eighth-day creation by citing Gen 5:1, which states that Adam was made in "the image of God" (as in Gen 1:27). Matthew 19:4 also undermines the eighth-day creation because it portrays all humans as descended from the sixth day of creation where humans were made "male and female." While Gen 5:1 and Matt 19:4 contain verbal parallels to Gen 1:26-27, Ps 8:4 does not. Therefore, its application to the imago Dei requires a further hermeneutical step. The verse reads, "What is man that thou are mindful of him? And the son of man, that thou visitest him?" Creation is obviously in view in Ps 8, as it speaks of "the work of [God's] fingers" (v. 3), but the key is in the phrase "son of man." Early Pentecostals, like other Christian interpreters before them, would recognize Ps 8:4 as a Messianic reference; but, according to the eighth-day creation theory, a son of "man" would be of the sixth-day race (Gen 6:1-2) and could not function as the redeemer. As stated above, the redeemer descends from Eve, who was created on the eighth day. Inasmuch as Jesus is both "son of man" and redeemer, the eighth-day creation theory must be invalid.

\section{$4 \quad$ Sanctification}

Sanctification is the fourth and final doctrine that is supported by references to the psalms. Under the heading "Important Questions - Bible Answers," we find questions about the "witness of the Spirit," the "immortality of the soul," second

20 Douglas Jacobson, Thinking in the Spirit: Theologies of the Early Pentecostal Movement (Bloomington, IN: Indiana University Press), 28-31.

21 Parham's theology of creation and the races is examined by Jacobson, Thinking in the Spirit, 30. An early Pentecostal refutation of the doctrine of two creations appears in PE 54 (Aug 1914): 3. 
chances after death, conditions for divine healing, "worldly dress," and sanctification. The question about sanctification reads, "Does the Word teach that after you are saved you should seek sanctification as a second work of grace?” The answer (in the affirmative) is proven by a string of biblical quotations: John 17:17; 1 John 1:7; 1 John 1:9; Eph 5:25-27; Rom 6:6; 2 Cor 7:1; Heb 13:12; and Ps 51:7, which states, "Purge me with hyssop, and I shall be clean: wash me, and I shall be whiter than snow."22 The connection between Ps 51:7 and the other texts on sanctification is found in the shared language of cleansing. "The blood of Jesus ... cleanses us from all sin" (1 John 1:7). "He is faithful to ... cleanse us from all unrighteousness" (1 John 1:9). "Christ also loved the church... that he might sanctify and cleanse it" (Eph 5:25). "Let us cleanse ourselves ... perfecting holiness" (2 Cor 7:1). The emphasis on cleansing language suggests that the writer views sanctification as more than a declarative and positional setting apart for God's use. The biblical texts chosen by the writer emphasize the purifying effect of sanctification; therefore, like John Wesley, the writer views sanctification as a cleansing from all sin; and like Wesley, a text from the OT is just as relevant as one from the $\mathrm{NT}^{23}$

\section{THE PSALMS AS ALLEGORIES}

Like other Christian interpreters at the turn of the twentieth century, Pentecostals were aware of allegorical methods. My search of the periodicals reveals that allegory was an accepted practice in the early Pentecostal movement; but, unlike the Church Fathers, Pentecostals do not appear to have considered allegory as a method that was applicable to any and all texts. The allegorical method was mostly restricted to the Royal Psalms and other psalms that were deemed “Messianic” (e.g. Ps 22). ${ }^{24}$ The Wesleyan-Holiness periodicals 1906 and 1915

22 AFO 30 (Feb 1915): 2.

23 Cf. Wesley's use of Ezek 36:25 "I will sprinkle clean water upon you and you shall be clean.” See, for example, John Wesley, The Works of the Rev John Wesley, 3rd ed. (London: Wesleyan Methodist Book Room, 1872), 5:166; 6:19, 287; 8:294; 10: 191; 11: 389; 12: 416. Regarding sanctification language, see also the discussion below regarding Ps 66:10. The doctrine of sanctification is also supported by appealing to Ps 1 (BM 6/138 [Aug 15, 1913]: 4); Ps 4:3 (CGE 6/47 [Nov 20, 1915]: 2); and Ps 91 (BM 2/29 [Jan 1, 1909]: 4). The doctrine of total depravity is discerned from Ps 51:5 (CGE 6/31 [July 31, 1915]: 3). See also the support for general revelation found in Pss 8:1 and 19:1 (BM 3/52 [Dec 15, 1909]: 1) and the return of Jesus in Ps 102:16 (BM 3/55 [Feb 1, 1910]: 1. The following citations were used to defend the exuberance of Pentecostal worship: Ps 47:1 in BM 1/9 (Mar 1, 1908): 1; Ps 126:1-3 in BM 3/49 (Nov 1, 1909): 4; Ps 119:120 in CGE 1/2 (Mar 15, 1910): 6 and CGE 5/24 (June 13, 1914): 5.

24 However, even Ps 22 was not always used in the allegorical/typological sense. Cf. BM 7/145 (Dec 1, 1913): 4; CGE 6/25 (June 19, 1915): 1; CGE 6/47 (Nov 20, 1915): 4. Other allegorical uses of the Psalms include Ps 45 in $B M$ 2/31 (Feb 1, 1909): 2; 
have sixteen references to Ps 45, a text that was interpreted as an allegory of the Church, the Bride of Christ. In a substantial article entitled "The Bride of Christ," we read the following:

The Psalmist in speaking of the Bride of Christ, says, "Upon Thy right hand did stand the queen in gold of Ophir" [Ps 45:9]. Gold of Ophir was the finest gold. The Bride will stand before Him in the purest gold, the holiness of Christ. He says, "Forget also thine own people and thy father's house, so shall the King greatly desire thy beauty" [Ps 45:10-11]. You must turn your back on everything of the world, and follow after Jesus with all of your heart, soul, mind and strength. And the day will come when you will stand beside the King robed in the finest of gold ... The Bride of Christ may have no place to lay her head except as God provides for her, yet she can say that her merchandise is good. It is not worldly goods or houses and lands but souls redeemed. She holds the truth of this wonderful and mighty Gospel, the most pure and glorious gift that ever came into this world. "she maketh herself coverings of tapestry, her clothing is silk and purple" [Prov 31:22]. She is arrayed in Royal garments, the holiness of the bride of Christ. "The King's daughter is all glorious within; her clothing is of wrought gold.” Psalm 45:13.25

Psalm 45 is a Royal Psalm that praises the king: "Thou art fairer than the children of men: grace is poured into thy lips: therefore God hath blessed thee forever" (v. 1). The king is praised for his glory, might, majesty, and righteousness. The psalm continues, "Thy throne, O God, is for ever and ever: the scepter of thy kingdom is a right scepter. Thou lovest righteousness, and hatest wickedness: therefore God, thy God, hath anointed thee with the oil of gladness above thy fellows" (vv. 6-7). The second half of the psalm celebrates the king in relation to his wife, his daughters, and his children.

Any psalm that mentions the king is automatically connected to Jesus Christ, and Ps 45 is no exception to this rule. Beyond the common allegorical concept of the Messianic Psalms, however, Ps 45:6-7 has the further distinction of being cited in the NT (Heb 1:8-9) where it is interpreted as a reference to Jesus. It follows that if the "king” signifies Jesus, then the "queen" must signify the Church, the Bride of Christ. The figure of the queen is expanded on by comparing the queen's golden garment to the believer's garment, which is the "holiness of Christ." Inasmuch as the "daughter" must forget her "own people” (Ps 45:10), the believer must turn away from "everything of the world, and follow after Jesus.” Apparently, both the queen and the king's daughter (Ps 45:13) represent the Bride of Christ that is "arrayed in Royal garments."

Pss 20:5 and 60:4 in $B M$ 2/40 (June 15, 1909): 4; and Ps 29:9 in BM 3/68 (Aug 15, 1910): 4.

25 AFO 32 (June-Aug 1915): 2. 
The quotations from Ps 45 evoke an emotive response from the writer, who appeals to the reader to "turn your back on everything of the world, and follow after Jesus with all of your heart, soul, mind and strength.” Moreover, the Bride holds the "most pure and glorious gift that ever came into the world." The language of Ps 45 and subsequent interpretation by the Pentecostal writer evoke deep and powerful feelings.

\section{THE PSALMS AS ANALOGOUS TO PENTECOSTAL EXPERIENCE}

The third category of citations consists of testimonies in which the experience of the writer is believed to be analogous to the experience of the psalmist. Analogical interpretation is a narrative, theological approach, but it is not the same as typological, spiritual, or allegorical methods, which take an OT text and bring it forward into a NT context. The analogical approach takes the reader's present experience and carries it back into the OT narrative context. ${ }^{26}$ Two biblical texts are cited in this fashion: Ps 66:10 and Ps 23.

\section{$1 \quad$ Psalm 66:10}

A woman who identifies herself as Sister Watts offers a personal testimony in which she recounts her various experiences at the Azusa St. revival. She writes that on her very first visit to the meeting she was wonderfully baptized in the Holy Spirit and spoke in tongues. However, the glory of her spiritual experiences did not prevent her from suffering severe tests and trials. She continues:

\footnotetext{
26 What I am calling the analogical approach had its beginning, in my mind, when I preached a series of sermons from the book of Hebrews; and, at the same time, I became aware of the views of John Bright, The Authority of the Old Testament (Nashville: Abingdon, 1967), 208-209, who suggests that "The Old Testament rightly heard, places me in my B.C. dilemma” (208-209). On the one hand, he argues that "we must not impose Christian meanings" on the OT (p. 184). On the other hand, he insists, "Every Old Testament text, if rightly heard, has its word for us today" (p. 212). My hermeneutic, forged in the praxis of pastoral ministry, has been refined also by engagement with Brueggemann's rhetorical-theological hermeneutic. See Walter Brueggemann, The Bible Makes Sense, 2nd ed. (Cincinnati: St. Anthony Messenger Press, 2003) and Walter Brueggemann, A Pathway of Interpretation: The Old Testament for Pastors and Students (Eugene, OR: Cascade Books, 2008). Other solutions to the dilemma of how to make the OT Relevant to a NT audience have been offered by Rudolph Bultmann, "Prophecy and Fulfillment," in Essays on Old Testament Hermeneutics, ed. Claus Westermann (Richmond: John Knox, 1963), 5075, and Friedrich Baumgartel, “The Hermeneutical Problem of the Old Testament," in Essays on Old Testament Hermeneutics, ed. Claus Westermann (Richmond: John Knox, 1963), 134-59. See also the more recent approach of Elizabeth Achtemeier, Preaching from the Old Testament (Philadelphia: John Knox, 1989), 56-59.
} 
My Jesus is more real to me than ever, the Holy Spirit is more jealous of my life and heart. I had suffered much in the purifying process, as gold in the fire or silver in the fire, Zech. 13:9 and Malachi 3:3, Psalm 66:10 [For thou, O God, hast proved us: thou hast tried us, as silver is tried]. We are tried and molded and purged and chastened and cleansed by the Holy Ghost, through the blood of Jesus Christ, the Author and Finisher of our Faith. ${ }^{27}$

She goes on to say that, at first, she "did not understand the sanctifying fire," and she thought that God had left her and had removed the Holy Spirit from her. After she had "prayed and cried to the Lord," she received assurance that God was forming and shaping her. She continued to "suffer over three weeks;" and, finally, she experienced a breakthrough in which she "rejoiced in a double portion of God's love and mercy." ${ }^{28}$ Her testimony is framed in such a way that it demonstrates the Pentecostal affections of gratitude, love, joy, and courage. ${ }^{29}$

Although Sister Watts affirms the connection between Ps 66:10 and the doctrine of sanctification, her primary purpose is not to argue a doctrinal point. Rather, her focus is on her experience of testing, which is analogous to the refining process described in Zech 13:9, Mal 3:3, and Ps 66:10. The psalms text, in particular, uses the first-person language of testimony: "thou [hast] proved us: thou hast tried us." Just as the Israelites were tested and tried, so also "we” (i.e. Christians) must be "tried and molded and purged and chastened and cleansed." The OT texts are selected here because of their common reference to the refining of gold and/or silver. The NT, while it describes testing as a normal part of Christian experience, does not use refining language. ${ }^{30}$

Another important implication of Sister Watts's testimony is the similarity between her experience and the biblical prayers of lament. Although Watts's article is a statement of praise rather than lament, her testimony displays the lament that preceded her praise. Note the following correlation between the

27 AFLA 1/8 (May 1907): 4. See a similar use of Ps 2:4 in BM 3/66 (July 15, 1910):

3.

28 AFLA 1/8 (May 1907): 4.

29 See again Land, Pentecostal, 47, 50, 52, 63.

30 An exception, of course, is 1 Cor 3:12-15. However, the Corinthian text speaks not of fire as a present purifying experience but of fire as a component of future judgment. Paul states that the nature of our "work ... shall be revealed by fire” (v. 13). The use of the Psalms analogically is quite common in the literature. See, for example, the use of Ps 73:2 in BM 6/137 (Aug 1, 1913): 1; Ps 22:11 in BM 7/145 (Dec 1, 1913): 4; Pss 42:8 and 34:7 in CGE 6/18 (May 1, 1915): 1, 4; Ps 25:14 in CGE 6/22 (May 26, 1915): 1; Ps 34 in BM 2/43 (Aug 1, 1909): 3; Ps 33:1 in BM 2/46 (Sept 15, 1909): 2; Ps 36:9 in BM 3/49 (Nov 1, 1909): 4; Ps 23:1 in BM 3/52 (Dec 15, 1909): 4; Ps 91 in $B M$ 3/63 (June 1, 1910): 4; Ps 3:3 in BM 3/65 (July 1, 1910): 1 and BM 3/66 (July 15, 1910): 2; Ps 19:11 in BM 4/81 (Mar 1, 1911): 3; and Ps 125:6 in Pentecostal Herald 1/4 (July 1915): 3. 
elements of the psalms of lament and Watt's experience. The correspondences are not exact, but are striking nonetheless:

Lament Form

1. Address to God

2. Complaint

3. Petition

4. Confession of trust

5. Assurance

6. Vow of praise

7. Descriptive praise

\section{Watts's Testimony}

"Jesus is more real to me than ever"

"I thought God had left me ... I suffered much ... I read my Bible, but none of the promises seemed for me, only judgment. Thus I suffered over 3 weeks.”

"I prayed and cried unto the Lord"

"We shall stand and come out more than conquerors ... [I] knew I loved Jesus"

"One morning I suddenly awoke by Jesus talking to me ... I clung to that promise"

The testimonies published in the early periodicals were mostly framed as statements of thanksgiving and praise; therefore, citations from the psalms of lament are infrequent. However, as Larry McQueen has documented, the Pentecostal practice of lament can be found throughout the early periodicals. ${ }^{31}$ The experience of lament often shows up, as it does here, in the writers' descriptions of their trials and prayers that led to their deliverances. ${ }^{32}$

31 See Larry McQueen, Joel and the Spirit: The Cry of a Prophetic Hermeneutic (Cleveland, TN: CPT Press, 2010), 70-76, who provides a helpful overview and introduction to prayers of lament in early Pentecostalism. 32 Cf., for example, the implied laments in AFLA 1/4 (Dec 1906): 1; AFLA 1/8 (May 1907): 4; AFLA 1/11 (Oct 1907-Jan 1908): 1; AFLA 1/12 (Jan 1908): 2; AFO 15 (JulyAug 1908): 4; BM 6/137 (Aug 1, 1913): 1; BM 6/139 (Sept 1, 1913): 2; $B M 7 / 143$ (Nov 1, 1913): 4; BM 3/65 (July 1, 1910): 1; Ps 65:22 in BM 5/112 (June 15, 1912): 4; $B M$ 8/174 (Sept 1, 1915): 3; LRE 1/7 (Apr 1909): 2; LRE 1/7 (Apr 1909): 5-6. 


\section{B Psalm 23}

Mrs. Daisy A. Wilkins, of Littleton, NC, cites Ps 23 in the following testimony regarding her recent illness:

I have been quite sick since I wrote you all last ... I am praising God for His keeping power that keeps me through health and sickness. Even through my darkest hours, the room was filled with angels singing sweet songs to cheer and strengthen me in faith. Many nights when everybody else would be asleep, the Holy Ghost would come in mighty power and fill my heart so I could only say what good old David did in the 23rd Psalm. Praise the Lord! ${ }^{33}$

Wilkins's testimony is quite unusual in that she does not reveal anything about her healing. Her use of past tense language suggests, however, that she was well at the time of writing; but she does not offer any praise to God for her healing. Instead of the common practice of giving thanks for an answer to prayer, Wilkins praises God for keeping her "through health and sickness" and through her "darkest hours." Like David, when she passed through "the valley of the shadow of death" (Ps 23:4), she found comfort in God's presence and in the songs of angels. The Holy Spirit cheered and strengthened her so that she could say with David, "thy rod and thy staff, they comfort me" (Ps 23:4). The affections of joy and gratitude are evident in the testimony.

Psalm 23 might be categorized as a psalm of trust, ${ }^{34}$ and Wilkins's letter to The Apostolic Faith is certainly an unapologetic statement of trust and confidence in God. Her experience, therefore, mirrors that of David as expressed in Ps 23. She has chosen to live in the world of the psalm and to claim its confession of trust as her own. Unlike some other early Pentecostals, Wilkins does not view faith and sickness as mutually exclusive; instead, she understands that a Christian can possess true faith and, at the same time, suffer illness.

\section{E THE PSALMS AS AFFECTIVE ARGUMENT}

Psalm 72:6-7 is quoted in an article entitled “The Baptism with the Holy Ghost.” The article begins by explaining the distinction between justification, sanctification, and Spirit baptism. It goes on to describe the effects of Spirit baptism, which include tongues, signs, power to witness, love, praise, and personal communion with God. We read, "This Holy Ghost is love, power, joy, blessing, wisdom and holiness. He will guide you and open the Scriptures to you.” The article also argues that sanctification is a prerequisite to Spirit baptism;

33 AFLA 1/12 (Jan 1908): 4.

34 John Goldingay, Psalms, vol. 1, BCOT (Grand Rapids, MI: Baker Academic, 2006), 345. Other scholars prefer to use the term "Psalm of confidence," e.g., Walter Brueggemann, The Message of the Psalms: A Theological Commentary (Minneapolis: Augsburg, 1984), 154. 
the writer asserts, "The baptism of the Holy Ghost comes on the sanctified, cleansed life.”

Consisting mostly of logical theological argument, the article changes direction and tone at the end and concludes with a declaration of the wonderful benefits of Spirit baptism. The final paragraph, which features the quotation from Ps 72:6-7, constitutes an appeal to the affect:

The most wonderful thing a man or woman can receive after being sanctified is the outpouring of the Holy Ghost in their heart. He is fire and rivers of salvation in you [sic] inmost being. Isaiah prophesied, speaking of the Holy Ghost as floods of water: "I will pour water upon him that is thirsty, and floods upon the dry ground; I will pour out My Spirit upon thy seed, and My blessing upon thine offspring." (Isaiah 44, 3.) "Until the Spirit be poured upon us from on high, and the wilderness be a fruitful field ...” (Isaiah, 32, 15.) Hallelujah! $\mathrm{O}$ it is so sweet and precious to receive this almighty baptism with the Holy Ghost in our souls. "He shall come down like rain upon the mown grass: as showers that water the earth. In His days shall the righteous flourish; and abundance of peace so long as the moon endureth.” (Ps. $72,6,7.)^{35}$

The quotations from Isaiah and the psalms demonstrate the writer's ability to utilize the affective dimension of the biblical text. The figurative language in this concluding paragraph creates in the reader a desire to receive the baptism in the Holy Spirit. Through the use of emotive metaphor, the writer shows that Spirit baptism is not only theologically orthodox, but it is "the most wonderful thing" a person can receive. Furthermore, it satisfies the "thirsty;" it makes wilderness fruitful; it is "sweet and precious;" it is "like rain;" and it produces flourishing and "abundance of peace." The vivid images spark the imagination and generate possibilities. The promise of "rain," which satiates the thirsty ground, causes the reader to hunger and thirst for the Holy Spirit. The hope of "peace" - in "abundance" no less - creates a longing in the hearts of those who suffer in the midst of conflict. ${ }^{36}$

It seems clear that the quotation of Ps 72:6-7 functions rhetorically as an affective argument, but the interpretation of the text as a reference to Spirit baptism requires further comment. On one level, the choice of texts is based upon the well-known metaphor of the Holy Spirit as water. For example, Jesus compares the Holy Spirit to "rivers of living water" (John 7:38), a metaphor that would have influenced the interpretation of early Pentecostals. The texts cited here (Isa 44:3 and 32:25) present the Spirit metaphorically as life-giving water. Pentecostal writers would be familiar also with the image of the Spirit as “early"

35 AFLA 1/11 (Oct 1907-Jan 1908): 4.

36 Other examples of Psalm texts used in affective argument include Ps 100:4 in BM 1/3 (Dec 1, 1907): 4, and Ps 104:4 in BM 3/55 (Feb 1, 1910): 4. 
and "latter rain" (e.g., Hos 6:3; Zech 10:1). After Joel promises a "latter rain" that will generate abundance (2:23-27), he declares next (v. 28) that the Lord will "pour out" his Spirit, and "sons and daughters shall prophesy." Many early Pentecostals even believed that the Pentecostal movement was the last-day fulfilment of these "latter rain" prophecies. ${ }^{37}$ Therefore, the psalmist's assertion that "He shall come down like rain ..." is easily connected to the other passages where Spirit and water/rain are joined.

Another hermeneutical key to the writer's interpretation is the fact that Ps 72, attributed to Solomon, is a Royal Psalm that praises the attributes of God's righteous king. The king is said to have dominion "unto the ends of the earth" (v. 8). "All nations shall serve him" (v. 11), and "he will save the souls of the needy. He shall redeem their soul ...” (vv. 13-14). The descriptions are so extravagant that the psalm is traditionally viewed by Christian interpreters as a Messianic prophecy. The king is said to be so great that "His name shall endure forever: his name shall be continued as long as the sun: and men shall be blessed in him: all nations shall call him blessed" (v. 17). The references to blessing recall the promise to Abraham (Gen 12:3; 22:18) that in his "seed" all the nations would be blessed, a promise that, according to Paul (Gal 3:8), is fulfilled in Jesus Christ. If the psalm describes the reign of Jesus Christ, then the references to life-giving rain, fruitfulness, and peace (which, after all, is a fruit of the Spirit) could be interpreted legitimately as allusions to the gift of the Holy Spirit.

\section{F THE PSALMS AS ASSURANCE AND COMFORT}

The fifth category consists of citations from the psalms that serve as encouragement to believers. Within what Brueggemann calls "the life of faith," these texts would function similarly to the psalms that he classifies as "Psalms of orientation.” This type of psalm provides a grounding, a worldview, an orientation for the believer and for the community. Psalms of orientation tell us that God is sovereign, God is good, and God is faithful to his covenant people. Regarding the psalms of orientation, Brueggemann writes,

some things are settled and beyond doubt, so that one does not live and believe in the midst of overwhelming anxiety ... God is known to be reliable and trustworthy. This community has decided to trust in this particular God. ${ }^{38}$

These psalms insist that evil is punished and good is rewarded. When life gets messy, the psalms of orientation remind us to trust in God because he will

37 Cf. Kenneth J. Archer, A Pentecostal Hermeneutic: Spirit, Scripture and Community (Cleveland, TN: CPT Press, 2009), 136-49. See also the reference to Ps 65:9 in BM 3/63 (June 1, 1910): 4.

38 Brueggemann, Message, 25. 
make things right. Like the Israelites, early Pentecostals used the psalms of orientation to create a world of "no fear." 39 They encountered a great deal of opposition; and because they were mostly poor, they suffered many deprivations and hardships. It is not surprising that they would look to the psalms for comfort and assurance in their times of great need.

\section{$1 \quad$ Psalm 91}

Psalm 91 is a psalm of trust that promises protection for anyone who will dwell "in the secret place of the Most High" (Ps 91:1). Because the Lord is a "refuge" (vv. 2, 4, 9) and a "fortress" (v. 2), those who "trust" in him (v. 2) will not "be afraid" (v. 5) of the "snare” and "pestilence” (v. 3), the "terror by night" or "arrow that flieth by day" (v. 5), the "destruction" (v. 6), the "plague” (v. 10), the "lion and adder" (v. 13), or any other peril. Moreover, "A thousand shall fall at thy side, and ten thousand at thy right hand; but it shall not come nigh thee” (v. 7); "There shall no evil befall thee, neither shall any plague come nigh thy dwelling" (v. 10). Thus, Brueggemann asserts that Ps 91 is

an intense acknowledgment of trust ... [that] has reckoned with real life threats, looking them straight in the face. But none will prevail against this God ... [these] are words of trusting people. ${ }^{40}$

John Goldingay observes what we all know - that the promises of Ps 91 "do not work out" in real life. ${ }^{41}$ Faithful children of God get sick and die; churches are burned; missionaries are murdered; and enemies sometimes prevail. The Israelites were also fully aware of life's unpleasant side, but they chose to confess an unwavering faith in God through texts like Ps $91 .^{42}$ The dark side of human life is addressed in the psalms of lament, which stand in the Psalter sideby-side with the psalms of trust. For example, Ps 22 begins with the cry, "My God, my God, why hast thou forsaken me?,” but in the very next psalm we hear this confession of trust: "The Lord is my shepherd, I shall not want." Commenting on the confident tone of Ps 91, Goldingay adds, "there is something

\footnotetext{
39 Brueggemann, Message, 25.

40 Brueggemann, Message, 157.

41 John Goldingay, Psalms, vol. 2, BCOT (Grand Rapids, MI: Baker Academic, 2006), 50.

42 The decision to assert an uncompromising approach to faith comes early in the Psalter. The First Psalm declares that the wicked are condemned, but the righteous person is "like a tree planted by the rivers of water, that bringeth forth his fruit in his season; his leaf also shall not wither; and whatsoever he doeth shall prosper” (Ps 1:3). However, we learn as soon as Ps 3 , that life is not fair - the righteous often suffer.
} 
profoundly authentic about maintaining such a conviction, even though experience can clash with it." 43

Psalm 91 is quoted frequently in the early Pentecostal periodicals. I located 16 references to Ps 91 in the Wesleyan-Holiness literature and 7 in the Finished-Work periodicals for a total of 23 references. These quotations functioned in most cases as encouragement to believers who were exposed to some kind of danger, such as contagious disease or contexts of violence. ${ }^{44}$ I found two citations of Ps 91 in The Apostolic Faith between 1906 and 1915, both referring to outbreaks of "the plague." A report entitled "The Revival in Portland" features descriptions of healings, miracles, and mighty outpourings of the Holy Spirit. Near the middle of the report, we find a brief narrative about a deadly epidemic. It reads:

When the plague in Portland was taking the children off at a fearful rate, the Lord healed all the Pentecostal flock as soon as it put in its appearance. Not one of them lost one of their family. The people were told to read the 91st Psalm, stand on the Word, and keep under the Blood, and fear nothing. ${ }^{45}$

The psalm uses hyperbole to emphasize God's power to protect those who trust in God. Although some early Pentecostals may have used Ps 91 as a "magical" text that guaranteed both physical and spiritual protection from all harmful forces, the writer of this article recognizes that Ps 91 cannot be taken literally. Although the psalm states that the pestilence "will not come nigh thee ... neither shall any plague come nigh thy dwelling” (vv. 6-7), in Portland the plague had come "nigh.” None were lost, but that does not mean none became sick. Some of the Pentecostals became ill and "the Lord healed all." In the context of a dreadful plague, the church was encouraged to trust God and "fear nothing." Ps 91 is believed to be just as valid for the Christian as it was for the Israelite. I would suggest that the Pentecostal reliance on Ps 91 is fully consistent with the psalm's rhetorical character and corresponds with Israel's stubborn confession of trust in God, even in the face of impossibilities.

The second citation of Ps 91 comes in a letter from China. The heading reads, "A Chinese brother writes of the plague,” and the letter states,

The plague is raging in Hong Kong, but we have the lintel and two side posts of our doors covered with the Blood of the Lamb. Ex. 12:23 [For the Lord will pass through to smite the Egyptians; and when he seeth the blood upon the lintel, and on the two side posts, the Lord

43 Goldingay, Psalms 2, 50.

44 Cf. Lee Roy Martin, "Psalm 91 and Pentecostal Spirituality: Dwelling in the Secret Place of the Most High," (paper presented at the Annual Meeting of the Society of Biblical Literature, San Antonio, TX, 20-23 November 2016).

45 AFLA 1/9 (June-Sept 1907): 1. 
will pass over the door, and will not suffer the destroyer to come in unto your houses to smite you.]. As yet none of us have caught the plague, not a single soul, but please look at Deut. 7:15 [the Lord will take away from thee all sickness, and will put none of the evil diseases of Egypt, which thou knowest, upon thee]. May the Lord have mercy. The total number of cases of the plague here have been near a thousand, and all fatal, except about 50. Not one of us are a bit afraid. Praise the Lord. Ps. 91:7 [A thousand shall fall at thy side, and ten thousand at thy right hand; but it shall not come nigh thee]. ${ }^{46}$

Once again, the God of the OT is believed to be the God of the Pentecostals. If the Israelites were saved by the blood of the lamb; then, in the same way, the Pentecostal believers could be saved by their faith in the blood of Jesus (the Lamb of God). If God would put no diseases upon faithful Israel, then neither would God put any diseases upon faithful Christians. The promises of Ps 91 were efficacious for the psalmist and for the twentieth-century believer.

Just as in the previous citation of Ps 91, this writer betrays the possibility that the psalmist's promises are not absolute. We read, "As yet none of us have caught the plague.” Note the words, "As yet," which indicate the writer's clear understanding of the dangers that persist. Furthermore, notice the poignant petition: "May the Lord have mercy." Apparently, it is not sufficient to quote the biblical promise and claim it; one must also appeal to the Lord's mercy through petition. In the psalm and in this letter from China, there remains an unresolved tension between complete trust in God and the ambiguities of life's dangers. One thing is resolved, however: the people of God should not be afraid. Therefore, in this letter to The Apostolic Faith (and in the earlier one as well) the use of Ps 91 is related to the Pentecostal affections of gratitude and courage.

\section{$2 \quad$ Psalm 37:7}

In “The Testimony of a Sunday School Teacher," we read a narrative regarding the writer's experience of Spirit Baptism:

I claimed my Pentecost through that precious Blood, and stood firm on the blessed promises of Luke xi., 13, and Luke xxiv., 49, and I praised Him for it until Friday, September 13th. Oh, that glorious night when Christ came into my heart in all His fullness. It was about twenty minutes to nine when I went into the meeting and they were singing "Rest in the Lord," the message He gave me on Thursday, Psalm xxxvii., 7 ["Rest in the Lord, and wait patiently for him”] ... oh, the unspeakable joy that flooded my soul ... the Spirit fell mightily upon me and I spoke in a strange language. ${ }^{47}$

\footnotetext{
46 AFO 15 (July-Aug 1908): 4.

47 AFLA 1/11 (Oct 1907-Jan 1908): 1.
} 
During the process of seeking God for the baptism in the Spirit, this teacher leaned heavily upon Jesus's promises as recorded in the Gospel of Luke. Firstly, Jesus promises that the Father will give the Holy Spirit to those who ask him. Jesus declares, "If ye then, being evil, know how to give good gifts unto your children: how much more shall your heavenly Father give the Holy Spirit to them that ask him?” (Luke 11:13) Secondly, Jesus assures his disciples that if they will wait in Jerusalem, the Holy Spirit will clothe them: "And, behold, I send the promise of my Father upon you: but tarry ye in the city of Jerusalem, until ye be endued with power from on high" (Luke 24:49). These two texts explicitly mention the Holy Spirit. Apparently, while the writer was praying for the Spirit and trusting the promises of Luke 11:13 and 24:49, God "gave” Ps 37:7 as a word of assurance: "Rest in the Lord, and wait patiently for him." We are not told the manner or mode of the revelation, only that God "gave" the Scripture. ${ }^{48}$ In this circumstance, the biblical text functioned as a word of assurance that the hearer would receive the Holy Spirit by resting in the Lord and "waiting patiently." The seeker's faith was strengthened even further when the very words of the psalm were heard ringing forth in the song of the congregation: "Rest in the Lord.” Although Ps 37:7 makes no mention of the Holy Spirit, the rhetoric of the text is broad enough to encompass any situation in which the hearer is awaiting God's action. The implication of the writer's use of Ps 37:7 is that Spirit baptism is a work of God that cannot be forced or attained by human effort; the seeker must rest from personal effort and surrender to the Spirit. ${ }^{49}$

\section{G SUMMARY AND CONCLUSIONS}

Although this study of the function of the psalms in The Apostolic Faith (19061915) explores only 25 of the 576 references to the psalms in the early periodicals, it has shown that the function and interpretation of the psalms in Pentecostalism were neither monolithic nor simple. The early writers utilized a variety of methods and approaches, depending upon their purpose for writing. On the one hand, the language of the Psalter was taken quite literally for the purposes of establishing doctrine; but, on the other hand, the language could also be taken allegorically, especially in relation to the Royal Psalms and others that

48 Another example of God's "giving” a Scripture to someone is found in BM 7/141 (Oct 1, 1913): 3. The writer tells about taking in a group of orphans in Nicaragua: "The day before these children were put in our care the Lord gave us the 127th Psalm.” See also a reference to Lord's giving of Ps 107 in BM 7/150 (Feb 15, 1914): 3.

49 Other biblical texts used as words of encouragement and assurance include Ps 27 (BM 6/126 [Feb 1, 1913]: 3); Ps 18:2 (BM 6/134 [June 1, 1913]: 4); Ps 118:6 (BM 7/143 [Nov 1, 1913]: 3); Ps 34:2 (BM 1/9 [Mar 1, 1908]: 2); Pss 23:4 and 118:17-18 (BM 2/34 [Mar 15, 1909]: 3); Ps 34:19 (BM 3/67 [Aug 1, 1910]: 2); and Ps 50:10 (BM 3/67 [Aug 1, 1910]: 3). 
are commonly known as Messianic Psalms. The practice of listing a number of biblical texts as support for doctrines - often without commentary - is consistent with Kenneth Archer's argument that early Pentecostals used the "Bible reading method." 50 The allegorical interpretation of the Messianic Psalms confirms Chris Green's argument that, for early Pentecostals, the OT speaks of Christ. ${ }^{51}$ However, the other interpretive approaches suggest that Green's point should be tweaked - the OT speaks of Christ, but that is not all it does. In addition to speaking of Christ, the OT speaks of the Father and of the Spirit; it speaks of the patriarchs and prophets; it speaks of Israel's long and tumultuous covenant relationship with God. Therefore, in many respects, the OT speaks with its own voice.

Through the analogical use of the psalms, the early Pentecostal understanding of reality was shaped by the biblical text, and Pentecostals saw themselves as living within the world of the text. The past, the present, and even the future were fused together by the Holy Spirit. ${ }^{52}$ The placing of ourselves in an OT context can appear strange to those of us who have been trained in the historical-critical methods, but the early Pentecostals were following a model of interpretation that is not uncommon in the NT. The writer of Hebrews, for example, compares the experience of the Hebrew Christians to that of the Israelites who, in Num 13-15, heard God's command to go forward. Those Israelites allowed fear and unbelief to cloud their judgment; and, therefore, they disobeyed God's command and subsequently died in the wilderness. The analogy

50 Archer, Pentecostal Hermeneutic, 99-102. Most of the texts examined in this study consist of references only to individual verses. Expositions of entire biblical passages are rare in the early Pentecostal periodicals, but see e.g., Ps 29, LRE 1/4-1/5 (Jan 1909); Ps 93, LRE 2/3 (Dec 1909); Ps 23, PE 85 (Apr 1915); Ps 32, PE 93 (June 1915); and Ps 141, PE (June 1915).

51 Chris E. W. Green, “'Treasures Old and New’: Reading the Old Testament with Early Pentecostal Mothers and Fathers," (paper presented at the Annual Meeting of the Society for Pentecostal Studies, Virginia Beach, VA, 29 February-3 March 2012). Green's very helpful proposal requires further explanation as it relates to the practice of OT interpretation. Without any clear hermeneutical direction, the open door into allegory can lead to a devaluing of the OT, inasmuch as the OT has no value in its own context. It is one thing to acknowledge (1) that the OT points to Christ and is ultimately fulfilled in Christ, and (2) that Christ in present everywhere in the Bible because, as part of the trinity, Christ is present whenever "God" is present; but it is another thing to require that every OT text have an allegorical meaning. Even in the NT, not every text is a direct comment on Jesus Christ. For an argument against the contemporary use of allegory, see Lee Roy Martin, "Pre-Critical Exegesis of the Book of Judges and the Construction of a Post-critical Hermeneutic,” EPhar 88 (2006): 338-53.

52 Cf. Land, Pentecostal, 55, 66-67. 
is stated clearly: "Take heed, brethren, lest there be in any of you an evil heart of unbelief, in departing from the living God" (Heb 3:12); and "Let us labour therefore to enter into that rest, lest any man fall after the same example of unbelief" (Heb 4:11). The Hebrew Christians faced the same questions of faith and challenges from the enemy as the biblical Israelites. ${ }^{53}$ Early Pentecostals were deeply infused with biblical ways of thinking and acting; therefore, it is not surprising that they would imitate the hermeneutical patterns of the NT writers. Their use of the OT as analogous to Christian experience is based upon a theological interpretation of Scripture that recognizes the commonality of all human lives that are lived by faith in the presence of God, no matter the location in time or geographical space. ${ }^{54}$

A number of conclusions can be reached from this exploration of The Apostolic Faith. Firstly, it is clear that early Pentecostals relied on both Old and NT as the Word of God. Secondly, they emphasized the overall unity of Scripture and downplayed the diversity of Scripture. ${ }^{55}$ Thirdly, they used intertextuality without reservation. ${ }^{56}$ Fourthly, their interpretations sometimes followed a rationalist, proof-texting approach; but, at other times, they followed a more literary, narrative, theological approach. In the fifth place, they appreciated the affective dimension of the Psalter and made wide use of it. Sixth, the early Pentecostal hermeneutic was thoroughly confessional.

Finally, I would suggest that the early Pentecostal approaches and contemporary scholarship might mutually inform one another to produce a genuinely Pentecostal approach to the psalms. Firstly, the use of the psalms as support for doctrine can be refined through critical engagement with exegetical and theological methods. Secondly, the use of the psalms as allegory/typology can be enhanced by a greater concern for consistency of application and by comparing the NT's appropriation of texts from the Psalter. Thirdly, the use of the psalms as analogies and as words of encouragement can be improved by

53 Cf. Paul's use of the wilderness narrative (1 Cor 10:1-13). Other texts where NT writers use the OT analogically might include Matt 4:4; 9:13; 13:14-15; 15:8-9; 24:15; 27:46; Mark 4:12; 7:6-7; 8:18; 13:14; 14:27; 15:34; Luke 4:4; 4:18-19; 8:10; 12:53; 20:17; 22:37; 23:46; John 2:17; 6:45; 12:40; 13:18; 15:25; Acts 1:20; 2:31; 4:25-26; Acts 28:26-27; Rom 1:17; 2:24; 3:13-18; 4:3, 22; 8:36; 9:25; 10:8, 11, 15-18; 10:20-21; 11:8-10; 1 Cor 1:31; 10:7; 14:21; 2 Cor 4:13; 6:2, 17; Gal 3:6, 11; 4:27; 1 Tim 5:18; Heb 11; 12:6; 12:25; 13:5-6; Jas 2:23; 1 Pet 1:24-25; 2:3, 9, 25; 3:14. 54 Cf. the similar, though more sophisticated, method of Walter Brueggemann, "Psalms and the Life of Faith: A Suggested Typology of Function," JSOT 17 (1980): 3-32, later expanded in Brueggemann, Message.

${ }^{55}$ Pentecostals would agree with the statement of John Bright that "the Testaments are inseparably bound to each other within the unity of a single redemptive history.” See Bright, Authority, 199.

${ }^{56}$ Cf. Green, "Reading the Old Testament," 15. 
giving attention to the theology, context, genre, and purpose of the psalms and by more thorough exegesis of our own situation, particularly in the area of Pentecostal spirituality and the affections. Fourthly, the use of the psalms as affective argument can be expanded by a broader appreciation of the rhetorical function of the affective language in the Psalter. It is hoped that this kind of approach can benefit the Pentecostal movement by integrating the study of the psalms with Pentecostal spirituality.

\section{BIBLIOGRAPHY}

Achtemeier, Elizabeth. Preaching from the Old Testament. Philadelphia: John Knox, 1989.

Alexander, Kimberly E. Pentecostal Healing: Models in Theology and Practice. JPTSup 29. Blandford Forum, UK: Deo Publishing, 2006.

Apostolic Faith, The. Los Angeles, CA: Apostolic Faith Mission.

Apostolic Faith, The. Portland, OR: Apostolic Faith Mission.

Archer, Kenneth J. A Pentecostal Hermeneutic: Spirit, Scripture and Community. Cleveland, TN: CPT Press, 2009.

Archer, Melissa L. "I was in the Spirit on the Lord's day": A Pentecostal Engagement with Worship in the Apocalypse. Cleveland, TN: CPT Press, 2014.

Baumgartel, Friedrich. “The Hermeneutical Problem of the Old Testament.” Pages 134159 in Essays on Old Testament Hermeneutics. Edited by Claus Westermann. Richmond: John Knox, 1963.

Bridegroom's Messenger, The. Atlanta, GA: International Pentecostal Church of Christ. Bright, John. The Authority of the Old Testament. Nashville: Abingdon, 1967.

Brueggemann, Walter. "Psalms and the Life of Faith: A Suggested Typology of Function.” JSOT 17 (1980): 3-32.

. The Message of the Psalms: A Theological Commentary. Minneapolis: Augsburg, 1984.

. The Bible Makes Sense. 2nd ed. Cincinnati: St. Anthony Messenger Press, 2003.

. A Pathway of Interpretation: The Old Testament for Pastors and Students. Eugene, OR: Cascade Books, 2008.

Bultmann, Rudolph. "Prophecy and Fulfillment." Pages 50-75 in Essays on Old Testament Hermeneutics. Edited by Claus Westermann. Richmond: John Knox, 1963.

Castelo, Daniel. “Tarrying on the Lord: Affections, Virtues and Theological Ethics in Pentecostal Perspective.” JPT 13/1 (2004): 31-56.

Christian Evangel/Pentecostal Evangel. Plainfield, IN / Findlay, OH: Assemblies of God.

Church of God Evangel, The. Cleveland, TN: Church of God.

Clapper, Gregory S. John Wesley on Religious Affections: His Views on Experience and Emotion and Their Role in the Christian Life and Theology. Metuchen, NJ: Scarecrow Press, 1989.

Dayton, Donald W. Theological Roots of Pentecostalism. Peabody, MA: Hendrickson Publishers, 1987.

Goldingay, John. Psalms. 2 vols. BCOT. Grand Rapids, MI: Baker Academic, 2006. 
Green, Chris E. W. Toward a Pentecostal Theology of the Lord's Supper. Cleveland, TN: CPT Press, 2012.

. “'Treasures Old and New': Reading the Old Testament with Early Pentecostal Mothers and Fathers." Paper presented at the Annual Meeting of the Society for Pentecostal Studies, Virginia Beach, VA, 29 February-3 March 2012.

Hollenweger, Walter J. The Pentecostals. Peabody, MA: Hendrickson, 1988.

Land, Steven J. Pentecostal Spirituality. Cleveland, TN: CPT Press, 2010.

Land, Gary. Historical Dictionary of the Seventh-day Adventists. 2nd ed. New York: Rowman \& Littlefield, 2015.

Latter Rain Evangel. Chicago, IL: Stone Church.

Jacobson, Douglas. Thinking in the Spirit: Theologies of the Early Pentecostal Movement. Bloomington, IN: Indiana University Press.

MacRobert, Iain. The Black Roots and White Racism of Early Pentecostalism in the USA. New York: St. Martin’s Press, 1988.

Martin, Lee Roy. "Pre-Critical Exegesis of the Book of Judges and the Construction of a Post-critical Hermeneutic,” EPhar 88 (2006): 338-353.

. "Psalm 91 and Pentecostal Spirituality: Dwelling in the Secret Place of the Most High.” Paper presented at the Annual Meeting of the Society of Biblical Literature, San Antonio, TX, 20-23 November 2016.

McQueen, Larry. Joel and the Spirit: The Cry of a Prophetic Hermeneutic. Cleveland, TN: CPT Press, 2010. . Toward a Pentecostal Eschatology: Discerning the Way Forward. JPTSup 39. Blandford Forum, UK: Deo Publishing, 2012.

Pentecostal Herald. Chicago, IL: Pentecostal Church of God.

Simpson, Albert B. The Fourfold Gospel. 4th ed. New York: Christian Alliance Publishing Co., 1890.

Thomas, John C. “'What the Spirit Is Saying to the Church': The Testimony of a Pentecostal in New Testament Studies.” Pages 115-129 in Spirit and Scripture: Exploring a Pneumatic Hermeneutic. Edited by Kevin L. Spawn and Archie T. Wright. New York: T\&T Clark, 2012.

Wesley, John. The Works of the Rev John Wesley. 3rd ed. London: Wesleyan Methodist Book Room, 1872.

Prof. Lee Roy Martin is a Research Fellow at UNISA and Professor of Old Testament and Biblical Languages at the Pentecostal Theological Seminary in Cleveland, Tennessee, USA.Email: lmartin@ptseminary.edu. 